\title{
THE RELATIONSHIPS BETWEEN ENVIRONMENTAL FACTORS AND SITE INDEX OF ANATOLIAN BLACK PINE (PINUS NIGRA ARN. SUBSP. PALLASIANA (LAMB.) HOLMBOE) STANDS IN DEMIRCI (MANISA) DISTRICT, TURKEY
}

\author{
GÜLSOY, S. * - ÇINAR, T. \\ Isparta University of Applied Sciences, Faculty of Forestry, 32260 Isparta, Turkey \\ (phone: +90-505-547-0196; fax: +90-246-211-3948) \\ *Corresponding author \\ e-mail:srkngulsoy@gmail.com \\ (Received $1^{\text {st }}$ Oct 2018; accepted $26^{\text {th }}$ Nov 2018)
}

\begin{abstract}
In this study, the relationships between the productivity of Anatolian black pine forests and the environmental variables were investigated in Demirci (Manisa) district of Turkey. Inventory study was performed on 40 stands totally. Ages and heights for 3 different plus trees in each stand were measured and site (bonitet) index values were calculated according to height at the age of 100 for the black pine. At the first stage, Pearson and Spearman correlation analyses were used to determine binary linear relations between productivity of the species and environmental factors in the district. Multiple regression analysis and regression tree method were performed to obtain the productivity models of the species, respectively. As a result of these analyses, it has been concluded that the lower slopes and flats with a smooth surface at average altitudes of $1000 \mathrm{~m}-1350 \mathrm{~m}$ are the most suitable areas for the productivity of Anatolian black pine in the district. Furthermore, it has been found that litter thickness on the soil is not a clear indicator for the productivity of the species in the natural stands. On the other hand, it has been determined that the north aspect significantly contributes to the productivity of this species in the elevations below $1000 \mathrm{~m}$ and all these relationships are especially related with water and nutrition contents in the environment.
\end{abstract}

Keywords: Anatolian black pine, climate, ecological modelling, productivity, site conditions

\section{Introduction}

Increasingly growing global population and industrialization result in irregular and uncontrolled exploitation of natural resources. This poses a great threat to all living communities including primarily to forests, which are considered as natural resources. At this stage, it is important to protect, ensure the sustainability and efficient management of forests that are globally crucial. Turkey is comprised of different geographical regions due to its climate, soil properties and topographic structure, and situated at the intersection of three continents and harbours three different phytogeographical regions; therefore, it hosts a very high biological diversity (Demir, 2013; Negiz et al., 2017). This also has reflections on the country's forestlands and allows the presence of many different species especially plant species, reptiles, bird and mammalian animal species, which all lead up to high biological diversity (Davis, 19651988; Kabalak and Sert, 2010). Such high biological diversity makes Turkey's forests nationally and globally vital, while it also requires thorough research on forests.

The Earth is covered with forests by $31 \%$ (3.9 billion hectare) (Keenan et al., 2015) forests covers $28.6 \%$ of the entire land area in Turkey, which accounts for 22.342.935 hectares (Kahriman et al., 2017). As regards the tree species, oak forests cover the largest area with 5.886.195 hectares, which is followed by brutian pine (Pinus brutia Ten.) forests with 5.610.215 hectares and black pine (Pinus nigra Arn.) with 4.244.921 
hectares (Anonim, 2015). Based on this piece of information, it can be suggested that all the abovementioned species play quite an important role for forestry strategies of the country.

Black pine which is one of the dominant species in the forest assets of Turkey is a primary forest tree species that has a very wide distribution area starting from South Europe up to Turkey (Atalay and Efe, 2012). It can be argued that black pine is a typical South European forest tree species that is ecologically and economically important in the abovementioned distribution area. The taxon of this species that is distributed in Turkey is Anatolian black pine (Pinus nigra Arn. subsp. pallasina (Lamb.) Holmboe), while it is reported that this taxon has minimum 15 geographical variations due to different climate and topographic condition in its natural distribution areas (Atalay and Efe, 2012). Anatolian black pine is mainly distributed at elevations of $400-1800 \mathrm{~m}$ in the Central Black Sea, Western Black Sea, Marmara, Aegean, Mediterranean and Central Anatolia Regions, while the boundaries of it distribution may partially vary depending on different geographical regions. This species is usually distributed up to $1400 \mathrm{~m}$ on slopes facing the sea in the highly mountainous areas of the Northern Anatolia region along with the Picea orientalis L. and Abies species, while it is distributed up to $1800 \mathrm{~m}$ along with the Pinus sylvestris L. species on the southern slopes of these mountains. Moreover, Anatolian black pine is distributed up to $1800 \mathrm{~m}$ on southern drier slopes in the Aegean and Marmara regions, while it establishes forests with Cedrus libani A. Rich, Abies cilicica Carr. and Juniperus species at elevations of $1000-1800 \mathrm{~m}$ in the Mediterranean region. This species is known to usually establish forests along with various oak species at elevation of 1200-1600 $\mathrm{m}$ in steppes in the Central Anatolia (Bahadir and Kenan, 2010; Atalay and Efe, 2012).

Anatolian black pine is subject to intensive production and management activities in forests at industrial scale especially thanks to its high quality and hard wood (Güller, 2012). It has a high economic return and high contribution to ecological cycle, it is contented with respect to soil requirements, it has a wider range of ecological tolerance compared to many other species and it is one of the species that have the greatest infiltration into steppe areas that have arid and semi-arid climate; therefore, it is commonly preferred for afforestation activities (Güner et al., 2011). It is crucial for Turkey's forestry strategies to obtain productive forests as a result of afforestation with this species. On the other hand, given that the forestlands are still shrinking at global scale, successful afforestation activities to be carried out by countries with their primary forest species are becoming more and more important because it is argued that the existing forests should be preserved or enlarged and degraded forests should be rehabilitated to become more productive with a view to ensuring the sustainability of multidimensional exploitation of forest ecosystems across the world (Faostat, 2014).

Demirci (Manisa) district is one of the important distribution areas of Anatolian black pine in Turkey. It is the second primary tree species with the highest distribution with 15.628 ha after oak species in this locality. There is 37.298 hectare of forestless land and 26.033 hectare of degraded forestland in the district (Anonymous, 2011). It is important at global scale and for the country's forestry strategies to determine the suitability of the concerned forestless lands and degraded forestlands for afforestation with Anatolian black pine for further productivity in the future. Therefore, this study was conducted to identify the areas in this locality that can be potentially productive for Anatolian black pine for rehabilitating degraded forestland to become productive and establishing new forests. 


\section{Material and Methods}

\section{Study area}

The study area was located at $38^{\circ} 54^{\prime}-39^{\circ} 10^{\prime}$ northern latitudes and $28^{\circ} 24^{\prime}-28^{\circ}$ eastern longitudes in the Northeast of Manisa province situated within the boundaries of the Aegean Region. According to Köppen-Geiger climate classification, the study area is classified into the sub-climate type of mild winters and very hot summers in the humid mid-latitude climate type with mild winters which is the most common climate type in Turkey (annual average total precipitation is $689 \mathrm{~mm}$ ) (Öztürk et al., 2017). The district is situated on Menderes (Saruhan - Menteşe) massif. Neogene deposits are the most common deposits in the locality. Kürtköyü formation of the basin starts with Early-Mid Miocene conglomerates while Yeşilköy formation contains sandstonemudstone alternations. Furthermore, Late Miocene-Early Pliocene aged Adala formation consisting of lime stones lies in the vicinity of Demirci located in this basin. As regards other formations apart from the abovementioned ones, basalt and gyans are also observed on volcanic masses such a andesite, dacite, trachyte and rhyolite (Helvac1, 2015).

Demirci district host various tree species due to its climate and topography. Pinus brutia Ten. var. brutia, Pinus nigra Arn. subsp. pallasiana (Lamb.) Holmboe, Quercus ithaburensis subsp. macrolepis, Quercus cerris L. var. cerris and Fagus orientalis Lipsky that is distributed in a partial area establish natural forests in the district (Anonymous, 2011).

\section{Data collection}

The research was conducted within the boundaries of 3 different Forest SubDirectorates (FSD) (Demirci FSD, Başalan FSD and Akpınar FSD) affiliated to Demirci Management Directorate in Manisa Demirci Locality. Once the stand types of the locality were integrated with the topographic maps, Anatolian black pine stands were mainly located at an elevation of $652 \mathrm{~m}-1693 \mathrm{~m}$ and moderately mountainous and partially high-mountainous regions. The study was conducted in 40 sampling plots each sized 20x20m in this elevation range (Fig. 1).
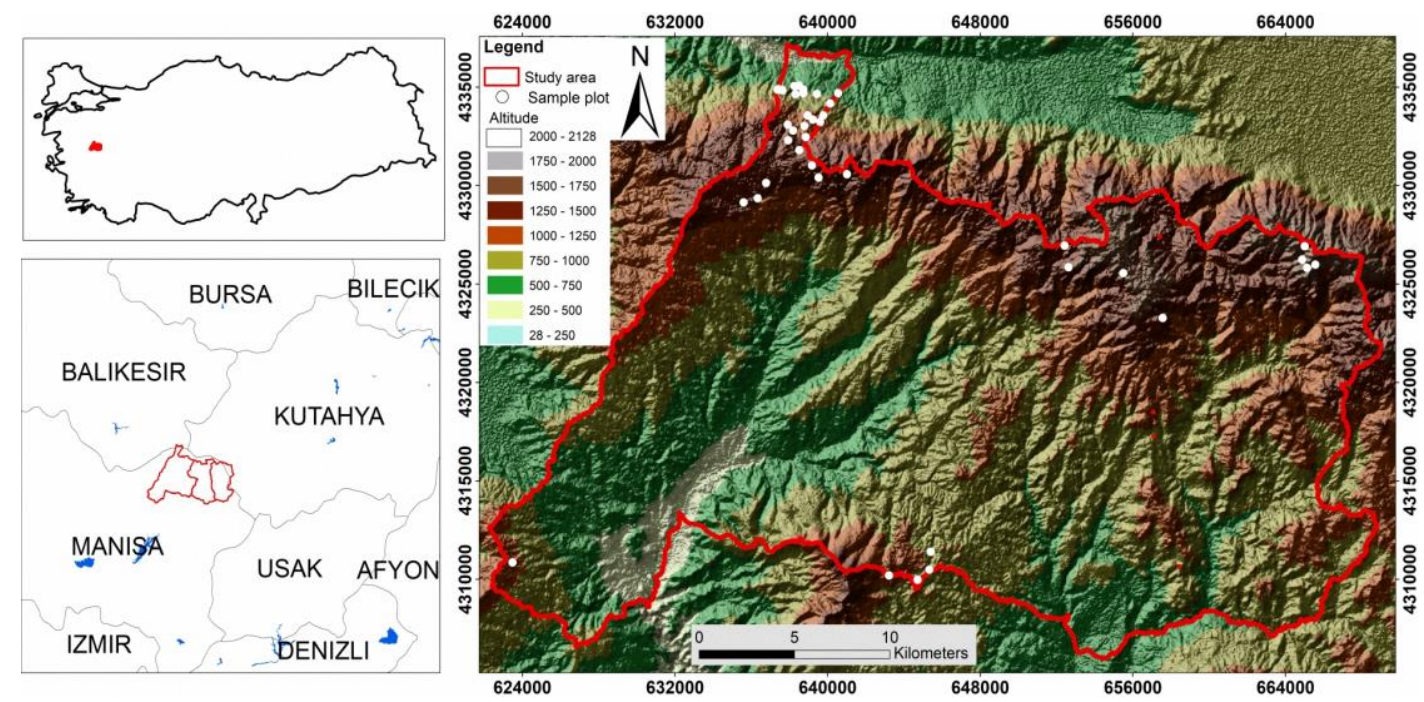

Figure 1. Sampling plot locations on the location map of Demirci (Manisa) district in Turkey 
In each sampling plot, minimum 3 plus trees (bonitet trees) with healthy were identified to determine the productivity of the species, their height $(\mathrm{m})$ was measured in planted position with Blume-Leisse equipment and age measurement was made on the core sample taken at breast height $\left(\mathrm{d}_{1.30} \mathrm{~m}\right)$ wwith an increment borer. Elevation was measured at 4 different points that were 20 meters distant from the centre of the sampling plots and perpendicular to the central point and the landform index ( $\mathrm{McNab}$, 2010) was calculated using the following formulation:

$$
\bar{Z}=\left(\left(Z_{1}-Z_{0}\right)+\left(Z_{2}-Z_{0}\right)+\cdots+\left(Z_{n}-Z_{0}\right)\right) / N
$$

In this formulation; $\bar{Z}$ : is landform index value, $Z_{0}$ : is the elevation of the central point of the sampling plots $(\mathrm{m}), Z_{1}, Z_{2}, Z_{n}$ : refer to the elevation of the edge point of the sampling plot $(\mathrm{m})$ and $N$ : refer to the number of measurements at the edge point of the sampling plots.

With another study during the field surveys, the slope position was determined taking account of the average distance from the upper edge of the hill to the positon of the sampling plot and the terrain surface (flat, undulated, concave, convex) was determined through the observations on the plots. Moreover, surface stoniness (\%) was determined with iron bar penetration method at 10 points randomly designated inside the sampling plot. After these steps, a soil pit was dug in each sampling plot by which soil depth (m) was determined, while the total litter thickness $(\mathrm{cm})$ was measured from the organic layer of the pit surface. As a result of these inventory studies, the slope degree of the sampling plots ranged from $4^{\circ}$ to $61^{\circ}$ while Anatolian black pine was distributed on slightly steep lands to very steep lands. The terrain surface of the sampling plots was mainly concave by $32 \%$ while the slope position was lower slope with the same percentage. The soil depth in the sampling plots ranged from $32 \mathrm{~cm}$ to $120+\mathrm{cm}$, while the litter thickness varied from $0.5 \mathrm{~cm}$ to $10 \mathrm{~cm}$; furthermore, surface stoniness was $1 \%$ $35 \%$. The skeleton content of the soil at a depth of $0-30 \mathrm{~cm}$ ranged from $0.5 \%$ to $60 \%$.

Soil samples were taken from surface of these pits at a depth of 0-30 cm, through which bedrock formation of the sampling plots were determined. Finally, latitude and longitude degrees of each sampling point were recorded at the mid-point with Global Position Systems (GPS) equipment, and these coordinates were uploaded to the digital maps from which information about some environmental variables was obtained. At this stage, first Digital Elevation Model (DEM) of the study area was developed. Contour maps with a scale of $1 / 25000$ were used to develop the DEM. Elevation (m), slope degree $\left({ }^{\circ}\right)$, topographic position index (De Reu et al., 2013), topographic roughness index (Cavalli et al., 2013), radiation index (McCune and Keon, 2002) and heat index (Beers, 1966) of the locality were determined using the DEM. The increase in the topographic position index value indicates the mountainous and hilly areas within a scale. Topographic roughness index is an indication of the roughness of the terrain. Radiation index takes values from 0 to 1 and this value is closer to 1 indicates more sunny places. Heat index is a value that reflects the average temperature in the environment as a combination of aspect and slope degree.

Annual average temperature $\left({ }^{\circ} \mathrm{C}\right)$ and annual average precipitation $(\mathrm{mm})$ variables were obtained from the climate maps available in the database at http://www.worldclim.org according to the coordinates of the sampling area (Fick and Hijmans, 2017). 
At the next stage of the study, soil samples taken from the field to the laboratory were air dried and sieved through $2 \mathrm{~mm}$ screen. Then, texture of thee soils was analysed using Bouyoucous hydrometer method, soil reaction was analysed using $\mathrm{pH}$-meter with glass electrode in $\mathrm{H}_{2} \mathrm{O}$ and $1 \mathrm{~N} \mathrm{KCl}$ solutions, organic carbon content was analysed with Walkley-Black method, total nitrogen content was analysed with semi-micro Kjeldahl method, lime content was analysed with Scheibler calcimeter method (Karaöz, $1989 \mathrm{a}, \mathrm{b})$. As a result of these soil analysis, the nitrogen content was found to vary from $0.008 \%$ to $0.104 \%$, while the organic matter content ranged from $1.13 \%$ to $5.67 \%$, and $\mathrm{pH}$ varied from 5.11 to 7.02 . The highest lime content was found to be $0.28 \%$ while lime was not found in most of the soils.

Finally, all variables classified in different types as categorical, present-absent and constant data were uploaded to Microsoft Excel program and a digital data matrix of environmental variables was obtained. The names of all these variables assessed in this study were coded before the statistical analyses (Table 1).

Table 1. Variables used in statistical analyses and their codes

\begin{tabular}{c|c|c|c}
\hline Variables & Code & Variables & Code \\
\hline Site index & stindx & Soil organic matter content $(\%)$ & orgmat \\
actph \\
Elevation $(\mathrm{m})$ & elvtn & Soil actual pH & limeco \\
Annual average temperature $\left({ }^{\circ} \mathrm{C}\right)$ & temptr & Soil lime content $(\%)$ & sand \\
Annual average precipitation $(\mathrm{mm})$ & precipt & Sand $(\%)$ & silt \\
Slope degree $\left({ }^{\circ}\right)$ & slopdg & Silt $(\%)$ & clay \\
Heat index & heatin & Clay $(\%)$ & soildp \\
Topographic position index & tpindx & Soil depth $(\mathrm{cm})$ & undult \\
Radiation index & radinx & Undulating hills & convex \\
Surface stoniness & surfst & Convex land & concav \\
Landform index & landix & Concave land & fltlnd \\
Tophist \\
Lowraphic roughness index & rougix & Flat land & talc \\
Lower slope position & lslope & Schist & gneiss \\
Upper middle slope position & lomslp & Talc & miggns \\
Upper slope position & upmslp & Gneiss & hematt \\
Litter thickness $(\mathrm{cm})$ & uslope & Migmatitic gneiss & graywk \\
Soil skeleton $(\%)$ & ltrthc & Gramatite & \\
Soil nitrogen $(\%)$ & nitrgn & & \\
\hline
\end{tabular}

\section{Statistical analsis}

The binary linear relations between the site index of Anatolian black pine and constant environmental variables were assessed with Pearson correlation analysis, while the relationships with categorical environmental variables were assessed with Spearman correlation analysis (Hauke and Kossowski, 2011). In order to determine the representative factor from the variables of sand, dust and clay that were estimated to cause multicollinearity problem due to the high correlation between them in ecological models, principal components analysis was performed (Bro and Smilde, 2014). Finally, in order to model potentially most productive site of Anatolian black pine in the district, stepwise multiple regression analysis (Tabachnik and Fidell, 2012) and regression tree technique (Özkan, 2012) were applied. For statistical analysis, SPSS Version 21.0 and PC-ORD Version 6.0 package software was used. 


\section{Results and Discussion}

According to the findings of this study, it was understood that the soils were classified into poor and moderate class as regards nitrogen content, poor to rich class in terms of organic matter content, moderately acidic and neutral class with respect to $\mathrm{pH}$ degrees, slightly calcareous or non-calcareous class with respect to lime content (Çepel, 1995). In a study conducted in a Pinus nigra forest in Sütçüler (Isparta) locality, the organic matter content of the soils was found to range from $0.55 \%$ to $13.4 \%, \mathrm{pH}$ from 5.2 to 7.6 and total lime content from $0.15 \%$ to $48.4 \%$ (Gülsoy, 2009). In another study conducted in Gölcük (Isparta), nitrogen content of the soils ranged from $0.003 \%$ to $0.053 \%$, organic carbon content from $0.042 \%$ to $1.071 \%$, and $\mathrm{pH}$ from 5.54 to 6.73 in Pinus nigra forest (Karatepe, 2004). As generally understood from these studies, the reserves in the soils may vary. This is considered to be the result of the variation in bedrock, climate and geomorphological characteristic of the localities where the studies are conducted. As a matter of fact, it was reported that the existing aspect difference at local scale even beyond different localities might lead to differences in reserve such nitrogen and organic carbon by affecting the litter decomposition rate (Karatepe, 2004).

The soil texture classes were determined with the assessment of soil particles according to sand, dust and clay content using the texture triangle developed the international particle diameter class (Cepel, 1988). The most common soil type in the sampling plot were sandy-loam (52.5\%) and loamy sand (27.5\%). On the other hand, 6 bedrock types were identified in the study area. The most common bedrock types were migmatite gnays and gnays. In a study conducted in the Aegean Region, it was reported that sandy-loamy soils with high percentage of small-diameter gravel and sand due to quarzite in the red Mediterranean forest soils that were formed on gnays bedrock were dominant (Atalay et al., 1990). Furthermore, these soil were reported to have good drainage and be permeable. Therefore, it could be suggested in this study that the soil types identified in the Anatolian black pine sites were influenced by the ganys bedrock type.

The mean age of plus trees obtained from all sampling plots was found to be 58.5, while the average height was $18.2 \mathrm{~m}$. After the plus trees in the sampling plots of the study were indexed to 100 years, the highest number of sampling plots was found in the site class II (45\%) while the lowest number of plots was in site class IV (7.5\%), whereas there was no sample in site class V (Kalıpsız, 1963). Pearson correlation analysis was performed to determine the relationship between the site index and independent variable in the form of constant data during the statistical assessment, while Spearman correlation analysis was performed for the environmental variables that were in the form of categorical data.

As a result of these analyses, a statistically significant positive correlation was found with site index and elevation $(\mathrm{r}=0.319)$, annual average precipitation $(\mathrm{r}=0.360)$ and flat landform $(\mathrm{r}=0.360)$; and a statistically significant negative correlation was found with annual average temperature $(\mathrm{r}=-0.323)$, topographic roughness index $(\mathrm{r}=-0.312)$ and upper slope position $(\mathrm{r}=-0.316)$.

At the second stage, in order to model productivity according to the site index values in the Anatolian black pine sites, stepwise multiple regression analysis was performed, and as a result 2 different model were obtained (Table 2).

Out of the models that were obtained, it was found that the $2^{\text {nd }}$ Model $\left(\mathrm{R}^{2}: 0.281\right)$ was more explanatory. In this model, flat landform and lower-middle slope position were the variables that involved in the model. Both of these variables had a positive contribution 
to the model. 8 of 40 sampling plots that were studied had flat landform while their average site index value was found to be $30.0 \mathrm{~m}$, while the average site index value was 25.1 in 32 sampling plots with different landforms. Therefore, there was an average difference of $4.9 \mathrm{~m}$, which was reflected to the model. The site index value of lowermiddle slope position, which was the other environmental variable in the model, in 10 sampling plots was found to be $28.0 \mathrm{~m}$, whereas the average site index value of the sampling plots with other slope position was $25.5 \mathrm{~m}$. Again the difference of $2.5 \mathrm{~m}$ between these values resulted in statistically important difference in the model.

Table 2. Findings of stepwise multiple regression analysis

\begin{tabular}{|c|c|c|c|c|c|}
\hline Models & $\mathbf{R}^{2}$ & p & \multicolumn{2}{|c|}{ Model variables } & VIF \\
\hline 1 & 0.186 & 0.005 & $\begin{array}{l}\text { Constant } \\
\text { fltlnd }\end{array}$ & $\begin{array}{l}25.13 \\
4.193 \\
\end{array}$ & 1.000 \\
\hline 2 & 0.281 & $\begin{array}{l}0.002 \\
0.033\end{array}$ & $\begin{array}{l}\text { Constant } \\
\text { fltlnd } \\
\text { lomslp }\end{array}$ & $\begin{array}{c}24.191 \\
5.424 \\
3.277\end{array}$ & $\begin{array}{l}1.021 \\
1.021\end{array}$ \\
\hline
\end{tabular}

Although the model obtained here was considered valid, the determination coefficient was very low due to the current $\mathrm{R}^{2}$ value. For that reason, Regression tree method was applied at the next stage of the study to model productivity in the Anatolian black pine stands. The tree model obtained as a result of the analysis was statistically important, while the $\mathrm{R}^{2}$ value of the model was found to be 0.709 (Fig. 2).

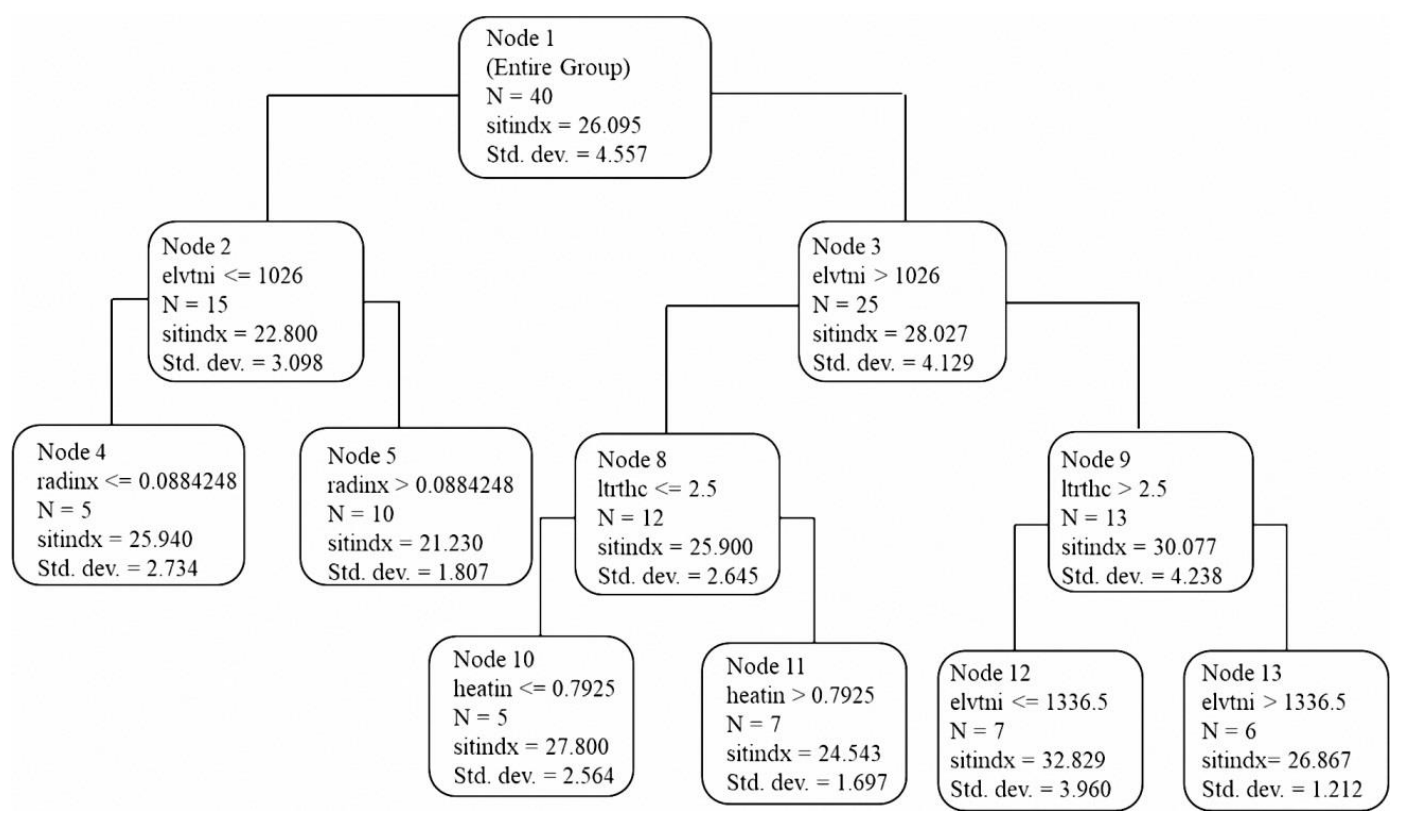

Figure 2. Model dendrogram obtained by regression tree technique

In the tree model, there were 6 different open-ended nodes, the highest contribution to the model was made by elevation $(100 \%)$, litter thickness $(28 \%)$, radiation index $(20 \%)$ and heat index $(8 \%)$, respectively. In case when the elevation ranged from 1026.0 to $1336.5 \mathrm{~m}$ and litter thickness was greater than $2.5 \mathrm{~cm}$ in the district, the highest site index value was found $(32.8 \mathrm{~m})$. The fact that litter thickness was higher in 
areas where Anatolian black pine was productive might initially make one think that the average decomposition was slow, but it indicated that actually productivity should be low. Nevertheless, this is not the case. To clarify this result, organic matter content of sampling plots with a litter thickness of $2.5 \mathrm{~cm}(3.11 \%)$ was compared with the organic matter content of sampling plots with a litter thickness lower than $2.5 \mathrm{~cm} \mathrm{(3.05 \% ).} \mathrm{The}$ assessment made revealed that there was no significant difference between the soils with respect to organic matter content and the soils were humic in both cases $(2.1 \%$ $4.0 \%)$ (Çepel, 1995). This showed that the litter ratio at the top layers of the soil (0-30 $\mathrm{cm}$ ) in Anatolian black pine stands in the district might not be a precise indicator for the organic matter ratio in the mineral soil part and thus for the productivity of the species.

A holistic evaluation of the findings obtained at this stage would demonstrate that an integrated interpretation of the models with binary linear analyse applied at the first stage was extremely important for the explanation of the concerned relationships. The positive relationship of the productivity of Anatolian black pine with flat landform, elevation and precipitation and the negative relationship with annual average temperature, topographic roughness index and upper slope positions in the binary linear relationships is an important finding that explains the increased productivity of the species in areas where the litter thickness in the model increased. To be clearer, this is considered to be a result of the thickness of the litter that accumulated without any carry-over on flat lands at the most optimum elevation range (around 1000-1350 m) and climate conditions suitable for the productivity of the species or the thickness of the litter that multiplied on lower slopes due to carry-over from the upper and middle slopes. Therefore, it is thought that the primarily dominant environmental factor that influenced the productivity of the species was actually optimum climate condition affected by elevation, while the secondary factor were the condition under which the species used water and nutrient at optimum level under the soil and geomorphological factors that were shaped by lower slope position and flat land as a whole.

These comments are consistent with the studies reporting that productivity increased under optimum climate conditions influenced by elevation and optimum water and nutrient economy conditions affected by slope position in Anatolian black pine stands (Özkan and Gülsoy, 2009; Güner et al., 2011; Özkan, 2013; Gülsoy et al., 2014; Güner et al., 2016). For example, in a study conducted in Dedegül mountain (Beyşehir) locality, climate conditions influenced by elevation, landform position and soil depth were the most dominant environmental factor that affected the productivity of Anatolian black pine just like in this these (Özkan et al., 2008). It was also reported in the study that the species could more easily overcome water deficit in summer period on lower slopes at an elevation of $1600 \mathrm{~m}-1800 \mathrm{~m}$ and deep soils and thus keep its productivity high. It is possible to interpret the relations in this context through the water and nutrient economy, which are shaped indirectly, in terms of elevation, climate, slope position and soil depth. Moreover, it was reported in another study conducted in Eskişehir (Türkmendağı) locality that elevation was the dominant environmental factor that increased the productivity of the species and the site index increased especially in areas where precipitation increased in the most arid three months in summer period (Oğuzoğlu and Özkan, 2015). In another study conducted in recent years, it has been determined that the productivity of black pine has decreased after the 1970s in the Mediterranean basin, which is one of the most sensitive regions to climate change (Janssen et al., 2018). It is stated that this situation is related to increasing summer temperature and drought in the region as a result of climate change trends in recent 
years. Therefore, all these remarks support the argument that the productivity of Anatolian black pine in the locality decreased depending on especially the severity of summer drought. As a matter of fact, there are other studies showing that soil nutrition content and water deficit due to environmental conditions and climate change are the most limiting factors for the productivity of the Anatolian black pine and other some tree species in the Mediterrenean Region (Sarris et al., 2007; Piovesan et al., 2008; Güner et al., 2016). In the light of this information, the findings of this study revealed that Anatolian black pine trees at the suitable elevation range and flat land in this locality minimized water deficit by decreasing the evapotranspiration amount at sufficient soil depth and tolerated summer drought on one hand, while on the other hand they exploited nutrients under these conditions at optimum level and kept their productivity dynamic level.

On the other hand, the finding obtained in this study demonstrated that the lowest site index value $(21.2 \mathrm{~m}$ ) was found in areas where the elevation was lower than $1026 \mathrm{~m}$ and the radiation index was greater than 0.88 . Radiation index closer to 1 pointed to the hottest aspect with the longest sunshine duration (Aertsen et al., 2010). Therefore, the fact that the radiation index was greater than 0.88 especially at lower elevations can be interpreted as areas with the harshest dry summer contrary to the abovementioned remarks and the decreased productivity of the species can be associated with this matter. Indeed, in a study highlighting the importance of aspect in addition to elevation for the productivity of the species, it was recommended that Anatolian black pine should be preferred on slopes at northern aspects with calcschist and dolomitic limestone and inclination greater than $40 \%$ and cedar should be preferred on slopes at southern aspects during the afforestation activities to be carried out at an elevation of $1500-2000 \mathrm{~m}$ in the Eastern Mediterranean Region (Polat et al., 2014).

\section{Conclusions}

Pinus nigra is widely used in afforestation activities and erosion control in Turkey and across the world since it has a wide distribution, tolerates harsh continental climate and habitat conditions and has the highest penetration into steppe compared to the other species, while it is also economically important. In this study, general site conditions and the areas where it can be most potentially productive were determined in Demirci district that is known to be one of the areas where Anatolian black pine, which is the taxon of this species distributed in Turkey, is widely distributed. In conclusion, it is possible to say that the effect of climatic conditions on water and nutrient economy in the environment is a very important factor reflected in the productivity of the species. This implies, indirectly, that climate change will affect the productivity of this species in the future. In this case, depending on the possible climate change scenarios in the future, it is also important to model the areas where this species can be the most productive. On the other hand, considering the wide distribution of this species, it is thought that there is a need for further studies at local scale in both Turkey and the world, through which the ecological requirements of the species can be clarified better and further and appropriate benefit can be obtained at global level.

Acknowledgements. We would like to thank Süleyman Demirel University Scientific Research Projects Coordination Unit for supporting our study under the project number SDÜ-BAPKB-4742-YL1-16. 


\section{REFERENCES}

[1] Aertsen, W., Kint, V., Van Orshoven, J., Özkan, K., Muys, B. (2010): Comparison and Ranking of Different Modelling Techniques For Prediction of Site Index in Mediterranean Mountain Forests. - Ecological Modelling 221(8): 1119-1130.

[2] Anonymous (2011): Manisa Demirci Amenejman Plan1. - Republic of Turkey General Directorate of Forestry Publications, 35 s., Ankara. (In Turkish).

[3] Anonymous (2015): Türkiye Orman Varlığ1-2015. - Republic of Turkey General Directorate of Forestry Publications, 32 p., Ankara. (In Turkish).

[4] Atalay, I., Efe, R. (2012): Ecological attributes and distribution of Anatolian black pine [Pinus nigra Arnold. subsp. pallasiana Lamb. Holmboe] in Turkey. - Journal of Environmental Biology 33(2): 509-519.

[5] Atalay, İ., Sezer, L. İ., Temuçin, E., Işık., Ş., Mutluer, M. (1990): The Factors affecting soil-forming in the Aegean Region. - Aegean Geographical Journal 5(1): 32-43.

[6] Bahadır, M., Emet, K. (2010): The analyse of essential tree species which present main climate types in Turkey, by using GIS. - Journal of TÜBAV Science 3(1): 94-105.

[7] Beers, T. W., Dress, P. E., Wensel, L. C. (1966): Notes and observations: aspect transformation in site productivity research. - Journal of Forestry 64: 691-692.

[8] Bro, R., Smilde, A. K. (2014): Principal component analysis. - Analytical Methods 6(9): 2812-2831.

[9] Cavalli, M., Trevisani, S., Comiti, F., Marchi, L. (2013): Geomorphometric assessment of spatial sediment connectivity in small Alpine catchments. - Geomorphology 188: 31-41.

[10] Çepel, N. (1988): Toprak ilmi: Ders kitabı. - İstanbul Üniversity, Faculty of Forestry Publications, Puplication No: 3416-389, 289 p., İstanbul. (In Turkish).

[11] Çepel, N. (1995): Orman Ekolojisi. - İstanbul Üniversity, Faculty of Forestry Publications, Puplication No: 426, 536 p., İstanbul. (In Turkish).

[12] Davis, P. H. (1965-1988): Flora of Turkey and the East Aegean Islands. - Vols. 1-9. Edinburgh University Press, Edinburgh, UK.

[13] De Reu, J., Bourgeois, J., Bats, M., Zwertvaegher, A., Gelorini, V., De Smedt, P., Chu W., Antrop, M., De Philippe, M., Finke, P., Van Meirvenne, M., Verniers, J. (2013): Application of the topographic position index to heterogeneous landscapes. Geomorphology 186: 39-49.

[14] Demir, A. (2013): A rising value in the sustainable development; the Turkey assessment in terms of biodiversity. - Istanbul Commerce University Journal of Science 12(24): 6774.

[15] Faostat (2014): Food and Agriculture Organization of the United Nations World Statistics website. - Retrieved from http://faostat.fao.org/site/626/DesktopDefault.aspx?PageID $=626$ \#ancor.

[16] Fick, S. E., Hijmans, R. J. (2017): WorldClim 2: new 1-km spatial resolution climate surfaces for global land areas. - International Journal of Climatology 37(12): 4302-4315.

[17] Güller, B. (2012): Effects of heat treatment on density, dimensional stability and color of Pinus nigra wood. - African Journal of Biotechnology 11(9): 2204-2209.

[18] Gülsoy, S., Süel, H., Özdemir, S., Özkan, K. (2014): Modeling Site Productivity of Anatolian Black Pine Stands in Response to Site Factors in Buldan District, Turkey. Pakistan Journal Botany 46(1): 213-220.

[19] Güner, Ş. T., Özkan, K., Çömez, A., Çelik, N. (2011): Woody indicator species of probable productive potantial areas of Anatolian black pine (Pinus nigra subsp. pallasiana) in the Inner Anatolia Region. - Ecology 20(80): 51-58.

[20] Güner, Ş. T., Çömez, A., Özkan, K., Karataş, R., Çelik, N. (2016): Modelling the productivity of Anatolian black pine plantations in Turkey. - Journal of the Faculty of Forestry Istanbul University 66(1): 159-172. 
[21] Hauke, J., Kossowski, T. (2011): Comparison of values of Pearson's and Spearman's correlation coefficients on the same sets of data. - Quaestiones Geographicae 30(2): 8793.

[22] Helvac1, C. (2015): Geological features of neogene basins hosting borate deposits: an overview of deposits and future forecast, Turkey. - Bulletin of the Mineral Research and Exploration 151: 173-219.

[23] Janssen, E., Kint, V., Bontemps, J. D., Özkan, K., Mert, A., Köse, N., İçel, B., Muys, B. (2018): Recent growth trends of black pine (Pinus nigra JF Arnold) in the eastern mediterranean. - Forest Ecology and Management 412: 21-28.

[24] Kabalak, M., Sert, O. (2010): Notes on four species of click beetles (Coleoptera: Elateridae) from Turkey. - The Coleopterists Bulletin 64(2): 160-162.

[25] Kahriman, A., Sönmez, T., Şahin, A. (2017): Tree volume tables for Calabrian pine in Antalya and Mersin region. - Kastamonu University Journal of Forestry Faculty 17(1): 922.

[26] Kalıpsız, A. (1963): Türkiye'de Karaçam (Pinus nigra Arnold) Mesçerelerinin Tabii Bünyesi ve Verim Kudreti Üzerine Araştırmalar. - Republic of Turkey, Ministry of Agriculture, General Directorate of Forestry Press 349(8): 48-57, İstanbul. (In Turkish).

[27] Karaöz, M. Ö. (1989a): Toprakların su ekonomisine ilişkin bazı fiziksel özelliklerinin laboratuarda belirlenmesi yöntemleri. - Journal of The Faculty of Forestry Istanbul University 39(2): 133-144. (In Turkish).

[28] Karaöz, M. Ö. (1989b): Toprakların bazı kimyasal özelliklerinin (pH, karbonat, tuzluluk, organik madde, total azot, yararlanılabilir fosfor) analiz yöntemleri. - Journal of The Faculty of Forestry Istanbul University 39(3): 64-82. (In Turkish).

[29] Karatepe, Y. (2004): Amount of nitrogen and organic carbon in soil and nitrogen and organic matter in forest floor of black pine (Pinus nigra Arn. supsp. pallasiana (Lamb.) Holmboe) stands developed in Gölcük (Isparta). - Turkish Journal of Forestry 2: 1-16.

[30] Keenan, R. J., Reams, G. A., Achard, F., De Freitas, J. V., Grainger, A., Lindquist, E. (2015): Dynamics of global forest area: Results from the FAO Global Forest Resources Assessment 2015. - Forest Ecology and Management 352: 9-20.

[31] McCune, B., Keon, D. (2002): Equations for potential annual direct incident radiation and heat load. - Journal of Vegetation Science 13: 603-606.

[32] McNab, W. H. (2010): Effects of landform on site index for two mesophytic tree species in the Appalachian Mountains of North Carolina, USA. - International Journal of Forestry Research 2010: 1-7.

[33] Negiz, M.G., Kurt, E.Ö., Şentürk, Ö. (2017): A case study on the account of speciescentered medicinal and aromatic plant species richness in Isparta-Yenişarbademli Region woodlands. - Turkish Journal of Forestry 18(4): 282-288.

[34] Oğuzoğlu, Ş., Özkan, K. (2015): Productivity distribution modelling of Anatolian Black Pine (Pinus nigra subsp. pallasiana var. pallasiana) in the Türkmen Mountain, Eskişehir. Biological Diversity and Conservation 8(2): 134-140.

[35] Özkan, K. (2012): Modelling ecological data using classification and regression tree technique (CART). - Turkish Journal of Forestry 13: 1-4.

[36] Özkan, K. (2013): Modeling Productivity of Crimean Pine by Using Fuzzy Logic Applications. - Eurasian Journal of Forest Science 1(1): 52-60.

[37] Özkan, K., Gülsoy, S. (2009): Effect of environmental factors on the productivity of Crimean pine (Pinus nigra subsp. pallasiana) in Sütçüler, Turkey. - Journal of Environmental Biology 30(6): 965-970.

[38] Özkan, K., Gülsoy, S., Mert, A. (2008): Interrelations Between Height Growth and Site Characteristics of Pinus nigra Arn. subsp. pallasiana (Lamb.) Holmboe. - Journal The Malaysian Forester 71: 9-16.

[39] Öztürk, M. Z., Çetinkaya, G., Aydın, S. (2017): Climate types of Turkey according to Köppen-Geiger climate classification. - Geography 35: 17-27. 
[40] Piovesan, G., Biondi, F., Di Fillipo, A., Alessandrini, A., Maugeri, M., (2008): Drought driven growth reduction in old beech (Fagus sylvatica L.) forests of the central Apennines, Italy. - Global Change Biology 14: 1265-1281.

[41] Polat, S., Polat, O., Kantarc1, M. D., Tüfekçi, S., Aksay, Y. (2014): Relationships between some environmental characteristics and site indices (H38) of Taurus cedar (Cedrus libani A. Rich.) and Black pine (Pinus nigra Arnold.) afforestation areas in the Kadıncik Basin of Mersin. - Journal of Forestry Research 1(1A): 22-37.

[42] Sarris, D., Christodoulakis, D., Koerner, C., (2007): Recent decline in precipitation and tree growth in the eastern Mediterranean. - Global Change Biology 13: 1187-1200.

[43] Tabachnik, B. G., Fidell, L. S. (2012): Using multivariate statistics (6th Edition). - US: Pearson. 